\title{
PEMBERDAYAAN MASYARAKAT DESA MENAYU LOR, MRISI DAN BETON, TIRTONIRMOLO, KASIHAN, BANTUL DALAM PROGRAM PENGELOLAAN PERPUSTAKAAN DESA
}

\author{
Oleh: \\ Waharjani dan mahasiswa KKN Alternatif devisi V.B \\ Universitas Ahmad Dahlan Yogyakarta \\ E-mail: Istiadina21@gmail.com
}

\begin{abstract}
Ringkasan
Salah satu permasalahan yang ada di masyarakat Desa Menayu Lor, Mrisi dan Beton, Kelurahan Tirtonirmolo, Kecamatan Kasihan, Kabupaten Bantul, Yogyakarta adalah minat baca masyarakat yang minim. Program ini bertujuan memberdayakan masyarakat Desa Mrisi, Menayu Lor, dan Beton dalam program Pengelolaan Perpustakaan Desa. Metode pelaksanaan program KKN meliputi: sosialisasi masyarakat dan praktek langsung. Dampak dari kegiatan KKN ini adalah: 1) tercipta kesadaran masyarakat akan pentingnya membaca, 2) tersedianya sarana ruang baca untuk umum, 3) masyarakat bertambah ilmunya dari buku-buku yang disediakan, 4) masyarakat bertambah ilmu untuk mengelola perpustakaan yang baik.
\end{abstract}

Kata kunci : Pemberdayaan, , Kelurahan Tirtonirmolo, perpustakaan

\begin{abstract}
Abstrak
One of the problems that exist in the community of Menayu Lor Village, Mrisi and Beton, Tirtonirmolo Village, Kasihan District, Bantul Regency, Yogyakarta is a minimal reading interest. This program aims to empower the community of Mrisi Village, Menayu Lor, and Beton in the Village Library Management program. Methods of KKN program implementation include: community socialization and direct practice. The impacts of this KKN activity are: 1) creating awareness of the importance of reading, 2) the availability of public reading room, 3) the community increases its knowledge of the books provided, 4) the community increases the knowledge to manage the good library.
\end{abstract}

Keywords: Empowerment, Tirtonirmolo Urban Village, Library

\section{A. PENDahuluan}

Kecamatan Kasihan berada di sebelah Utara dari Kabupaten Bantul. Kecamatan Kasihan mempunyai luas wilayah 3.437,957 Ha. Kecamatan Kasihan berada di dataran rendah dan beriklim seperti layaknya daerah dataran rendah di daerah tropis dengan dengan cuaca panas sebagai ciri khasnya. Suhu tertinggi yang tercatat di Kecamatan Kasihan adalah $34^{\circ} \mathrm{C}$ dengan suhu terendah $22^{\circ} \mathrm{C}$. Bentangan wilayah di Kecamatan Kasihan $80 \%$ berupa daerah yang datar sampai berombak dan $20 \%$ berupa daerah yang berombak sampai berbukit.Secara administratif, Kecamatan Kasihan dibagi atas 4 (empat) kelurahan, yaitu Kelurahan Bangunjiwo, Tirtonirmolo, Tamantirto dan Ngestiharjo. Masing-masing desa di terbagi dalam lingkup yang lebih kecil yaitu: Pedukuhan, dan RT. Kelurahan Tirtonirmolo merupakan salah satu Kelurahan dari 4 Kelurahan di Kecamatan Kasihan.

Kelurahan Tirtonirmolo terdapat 12 dusun/desa, diantaranya ada 3 dusun yang tergabung dari satu DPL, diantaranya Desa Menayu Lor, Mrisi dan Beton. Masyarakat desa 
di ketiga desa tersebut sebagian besar berprofesi sebagai petani dan tukang kayu. Agama mayoritas adalah Islam. Tingkat partisipasi warganya tergolong aktif.

Keadaan desanya tergolong sudah maju, namun ada beberapa permasalahan yang ditemukan di Desa menayu lor, mrisi dan beton antara lain: 1)

Pengelolaan bank sampah yang belum berjalan sesuai harapan, 2) Belum tersedianya perpustakaan untuk masyarakat umum, 3) Ketersediaan buku-buku anak dan orang dewasa yang masih minim, 4) minat baca masyarakat yang rendah

Peran serta dari masyarakat dalam pengelolaan perpustakaan desa akan menentukan keberhasilan program KKN UAD ini. Peran masyarakat sekecil apapun sangat di butuhkan, tidak hanya dalam bentuk baranag namun bantuan dalam bentuk tenaga atau masukan sangat membantu untuk terlaksananya program pemberdayaan ini.

Pada hakikatnya perpustakaan dan masyarakat adalah sesuatu yang tidak bias dipisahkan karena perpustakaan adalah produk manusia. Begitu juga terkait dengan perkembangan perpustakaan juga tidak terlepas dari perkembangan manusia. Oleh sebab itu, eksistensi perpustakaan yang lebih dari 5000 tahun ini masih tetap bertahan walaupun banyak hambatan dan rintangan (Sulistyo-Basuki, 1993). Di dalam ajaran agama Islam, sebagaimana kita ketahui bahwa perpustakaan memiliki kedudukan yang sangat penting, pedpmannya adalah perintah Allah yang pertama pada permulaan nubuwwah Nabi Muhammad SWA adalah "IQRA" (bacalah) yang sangat identik dengan fungsi utama perpustakaan.

Berdasarkan permasalahan tersebut, maka ditetapkan tujuan program KKN ini adalah memberdayakan masyarakat Desa Menayu Lor, Mrisi dan Beton dalam mengelola perpustakaan desa.

\section{B. METODE PELAKSANAAN}

Untuk mencapai tujuan yang diharapkan, program KKN di Desa Menayu Lor, Mrisi dan Beton dilakukan dengan pemberdayaan masyarakat melalui Sosialisasi masyarakat, dan praktek langsung. Ringkasan metode pelaksanaan beserta jam kerja efektif mahasiswa (JKEM) tersaji pada table I.

Tabel I. Metode, Kegiatan, JKEM dan keterlibatan mahasiswa

\begin{tabular}{|l|l|l|l|l|}
\hline No & Metode & Kegiatan & JKEM & $\begin{array}{l}\text { Jumlah } \\
\text { mahasiswa } \\
\text { yang terlibat }\end{array}$ \\
\hline 1 & $\begin{array}{l}\text { Pendidikan } \\
\text { masyarakat }\end{array}$ & $\begin{array}{l}\text { Mengadakan penyuluhan tentang } \\
\text { pentingnya membaca }\end{array}$ & $1 \times 3$ jam & 3 \\
\cline { 3 - 5 } & $\begin{array}{l}\text { Mengadakan penyuluhan tentang } \\
\text { pengelolaan perpustakaan }\end{array}$ & $1 \times 2 \mathrm{jam}$ & 3 \\
\hline 2 & \multirow{2}{*}{\begin{tabular}{l} 
Praktek \\
\cline { 3 - 5 }
\end{tabular}} & Pelatihan managemen perpustakaan & $1 \times 3 \mathrm{jam}$ & 6 \\
\cline { 3 - 5 } & Pembacakan buku untuk anak & $3 \times 2 \mathrm{jam}$ & 2 \\
\hline
\end{tabular}


Diterbitkan oleh Lembaga Pengabdian kepada Masyarakat

Universitas Ahmad Dahlan Yogyakarta

\section{HASIL, PEMBAHASAN DAN DAMPAK}

\section{Profil Desa}

Kabupaten bantul merupakan salah satu kabupaten yang ada di Daerah Istimewa Yogyakarta. Terdapat 7 kecamatan dalam Kabupaten Bantul salah satunya kecamatan kasihan. Pada kecamatan kasihan terdapat 20 titik penempatan KKN. Salah satunya ada di kelurahan tirtonirmolo yaitu desa Beton, Menayu Lor, dan Mrisi. Masing-masing dusun diisi oleh satu devisi KKN dengan jumlah total mahasiswa sebanyak 25. Ketiga Desa tersebut dibimbing oleh Bpk. Dr.Waharjani M.Ag.

Kelurahan ini terletak di sebelah timur kantor kecamatan kasihan ,Bantul, Daerah Istmewa Yogyakarta yang berada dekat dengan Pabrik Gula Madukismo. Kelurahan Ttirtonirmolo memiliki 12 dusun, antara lain ada dusun Menayu Lor, Mrisi dan Beton.

Dusun yang pertama adalah desa Menayu Lor. Desa menayu lor terdiri dari 465 penduduk. Batas wilayah dusun Menayu Lor pada sebelah utara dusun Jeblog, sebelah timur dusun Plurugan, sebelah selatan Jl. Ringroad Selatan dan di sebelah Barat adalah Dusun Menayu Kulon.

Secara umum sarana dan prasarana sudah ada di pedukuhan mulai dari tempat ibadah, poskesdus, posyandu dan lain-lain yang dibuat sesuai dengan kebutuhan masyarakat di wilayah tersebut. Salah satu sarana yang menjadi sasaran KKN Alternatif UAD LVI adalah tempat ibadah dan organisasi masyarakat. Tempat ibadah yang menjadi tempat pelaksanaan KKN UAD unit V.B.1 adalah Masjid Amar Ma'ruf Nahi Munkar yang terletak di RT 05 Menayu Lor, Kasihan. Meskipun demikian, jama' ah Masjid Amar Ma'ruf Nahi Munkar tidak hanya dari penduduk RT 05 Menayu Lor, tetapi juga penduduk RT 04 dan penduduk padukuhan Jeblog.

Mayoritas penduduk RT 05 beragama Islam dan sebagiannya lagi beragama Kristen, namun demikian hubungan antar agama terjalin sangat baik. Untuk kegiatan keagamaan bagi yang beragama Islam mempunyai rutinitas pengajian untuk ibu-ibu setiap malam senin 1 minggu sekali dan untuk bapak-bapak setiap malam rabu. Sebagian besar mata pencaharian masyarakat desa Menayu Lor adalah sebagai petani dan tukang kayu.

Dusun yang kedua adalah dusun Mrisi. Desa Mrisi merupakan salah satu lingkungan yang administrative masuk dalam wilayah kelurahan Tirtonirmolo, kecamatan Kasihan, kabupaten Bantul. Secara geografis Desa Mrisi terletak di sebelah utara desa Beton dan sebelah selatan desa Padokan serta sebelah selatan PT Madu Baru yang merupakan pabrik gula unggulan sering disebut juga dengan pabrik gula Madu Kismo. Desa Mrisi memiliki RT sebangak 12, yang terbagi atas tiga wilayah yaitu: RT 1, 2, 3, dan 4 termasuk desa Mrisi Utara, RT 5, 6, 7, dan 8 termasuk desa Mrisi Tengah, dan RT 9, 10, 11, dan 12 termasuk desa Mrisi Selatan. Desa Mrisi juga terdapat 5 masjid yaitu: Masjid Nur Salam, Masjid Al-Baro'ah, Masjid Grisinda, Masjid Al-Ikhlas dan Masjid Al-Irfan.

Penduduk desa Mrisi berdasarkan mata pencahariannya terbagi atas beberapa profesi yaitu profesi sebagai TNI/POLRI, PNS, Guru/dosen, mata pencaharian sebagai pengrajin industri, sebagai peternak, pedagang, petani, pegawai swasta/karyawan swasta, pembantu rumah tangga, wirausaha, arsitektur/seniman, dan pensiunan.

Jika dibandingkan dengan desa-desa lain Desa Mrisi sudah relative maju. Ada beberapa faktor yang menyebabkan desa Mrisi relative sudah maju dibandingkan desa-desa 
lainnya, faktor-fator ini antara lain: letak wilayah yang mudah terjangkau atau strategis, infrastruktur desa yang maju, pentingnya kesadaran akan pendidikan bagi perubahan dan kemajuan individual dan bersama, jiwa sosial yang tinggi. Letak wilayah Desa Mrisi yang mudah dijangkau membuat kehidupan masyarakat lebih berkembang karena lalu lintas ekonomi desa Mrisi yang mudah. Akses jalan yang cukup mudah dilalui oleh kendaraan darat roda dua maupun roda empat karena langsung terhubung ke jalan raya.

Semua sikap dan perilaku yang muncul dari masyarakat merupakan cerminan tingkat pola pikir dan pengetahuan masyarakat. Pendidikan di era zaman sekarang mutlak untuk pengembangan dan kemajuan disemua sektor kehidupan masyarakat. Begitu pentingnya pendidikan bagi kemajuan dan perubahan dalam masyarakat menyebabkan pendidikan dianggap sebagai pondasi yang menentukan pendidikan dianggap sebagai pondasi yang menentukan bagi caracther of nasion maupun caracther of building suatu bangsa.

Secara sosiologis kultural kehidupan masyarakat desa Mrisi masih sebagian ada pengaruh jawa kuno. Dalam kehidupan sosial hubungan antara warga masyarakat masih bersifat kekeluargaa, itu terlihat dari berbagai aktivitas dan kegiatan warga yang gotong royong dikerjakan secara bersama-sama maupun pada acara hajatan. Masyarakat desa Mrisi memiliki kegiatan rutin yang diadakan setiap bulan, seperti kerja bakti setiap minggu pertama, arisan bapak-bapak RT 5 setiap bulan minggu ke 2, arisan ibu-ibu setiap minggu, pertemuan PKK setiap pertengahan bulan, posyandu balita setiap bulan tanggal 11, dan posyandu lansia setiap bulan tanggal 20.

Masyarakat Desa Mrisi mayoritas beragama islam, fasilitas dan aktivitas keagamaan di Desa Mrisi sangatlah lengkap dengan adanya majelis pengajian rutin bapakbapak, majelis pengajian ibu-ibu, dan untuk anak-anak ada TPA setiap hari senin dan jumat di SD Muhammadiyah Mrisi serta Selasa, Rabu, Kamis dimasjid Nur Salam dan tim hadroh ibu-ibu masyarakat di desa Mrisi tergolong masyarakat yang religious. Hal ini terlihat dari antusias warga ketika melakukan sholat berjamaah setiap hari di Masjid. Sorak sorai masyarakat yang jauh-jauh hari untuk menyambut bulan suci ramadhan juga terlihat ketika masyarakat gotong royong untuk memperbaiki masjid Nur Salam agar terlihat lebih indah dan lebih nyaman untuk beribadah. Masyarakat desa Mrisi juga menyiapkan jauh-jauh hari untuk anggaran buka bersama atau takjil di bulan suci Ramadhan. Dana yang terkumpul dari warga terbilang sangat besar, dana yang terkumpul mencapai 48 juta Rupiah dana untuk takjil.

Dusun yang ketiga yaitu Dusun Beton. Dusun Beton sendiri terdiri dari sekitar 120 kepala keluarga, dengan 512 penduduk, batas wilayah dusun Beton sendiri pada sebelah utara bersebelahan dengan desa Karangpulih, sebelah selatan bersebelahan dengan dusun Bongkotan, sebelah timur merupakan dusun Karang tengah, dan bagian barat berbatasan dengan dusun Kasongan. Akses jalan menuju dusun beton cukup mudah dilalui oleh kendaraan darat baik roda dua maupun roda empat karena langsung terhubung dengan jalan raya besar yang menuju kota Yogyakarta dan karena letak dusun yang cukup strategis dan ramai kendaraan.

Dari segi masyarakat, dapat dikatakan masyarakat dusun Beton sudah cukup akrab dan dapat menerima kemajuan ataupun perubahan zaman, pemikiran penduduk dusun yang sudah maju, hal ini dapat dilihat dari masyarakat dusun yang memperhatikan pendidikan 
Diterbitkan oleh Lembaga Pengabdian kepada Masyarakat

Universitas Ahmad Dahlan Yogyakarta

anak-anak di dusun itu sendiri. Keakraban antar masyarakat dalam dusun beton juga dapat dikatakan kompak, karena masih diperlakukannya sistem musyawarah, kegiatan-kegiatan warga seperti pengajian dan rapat RT ataupun tingkat dukuh, selain itu, banyak kegiatan seperti pembagian jadwal ta'jil untuk puasa Ramadhan maupun puasa sunnah senin kamis yang di lakukan secara bergotong royong.

Dari segi ekonomi, mayoritas masyarakat di dusun Beton merupakan petani dan pengrajin. Hal ini dapat dilihat dari masih banyaknya sawah di sekitar desa, serta dilihat dari jumlah toko kerajinan di sekitar desa, terutama di sisi kiri dan kanan jalan utama desa Beton. Tapi tak hanya petani dan pengerajin desa beton juga memiliki pekerjaan yang beragam seperti guru, peternak, pedagang, karyawan dan berbagai jenis pekerjaan lainnya. Kemudian dari sisi kesehatan masyarakat desa beton cukup diperhatikan salah satunya dengan di adakannya aktivitas senam lansia (lanjut usia) rutin dan pengecekan gizi.

Desa Beton dikenal sebagai desa dengan tingkat religiusitas yang tinggi, hal ini di dukung dengan masyarakat desa Beton terutama RT 4 dan 5 yang memiliki warga dengan presentasi $100 \%$ muslim. Berbagai kegiatan keagamaan sering bahkan rutin di lakukan, salah satu kegiatan rutin yang juga menunjukkan ke kompakkan dari desa ini adalah puasa sunnah senin dan kamis. Pada hari senin dan kamis, warga desa Beton akan melakukan puasa dan berbuka puasa di Masjid Al-Habbah, sedangkan ta'jil sendiri diberikan oleh warga secara bergantian. Tak hanya itu, warga desa Beton juga memiliki berbagai kegiatan rutin seperti pengajian untuk Ibu-ibu, kajian Hadist yang dilaksanakan setiap dua minggu sekali, pengajin anak-anak, juga tadarus yang di peruntukkan bagi remaja setiap sabtu malam.

\section{Gambaran Pelaksanaan}

Gambar aktivitas mahasiswa KKN UAD dan masyarakat di Desa Menayu Lor, Mrisi dan Beton dalam program peningkatan fungsi perpustakaan desa pada gambar 4.

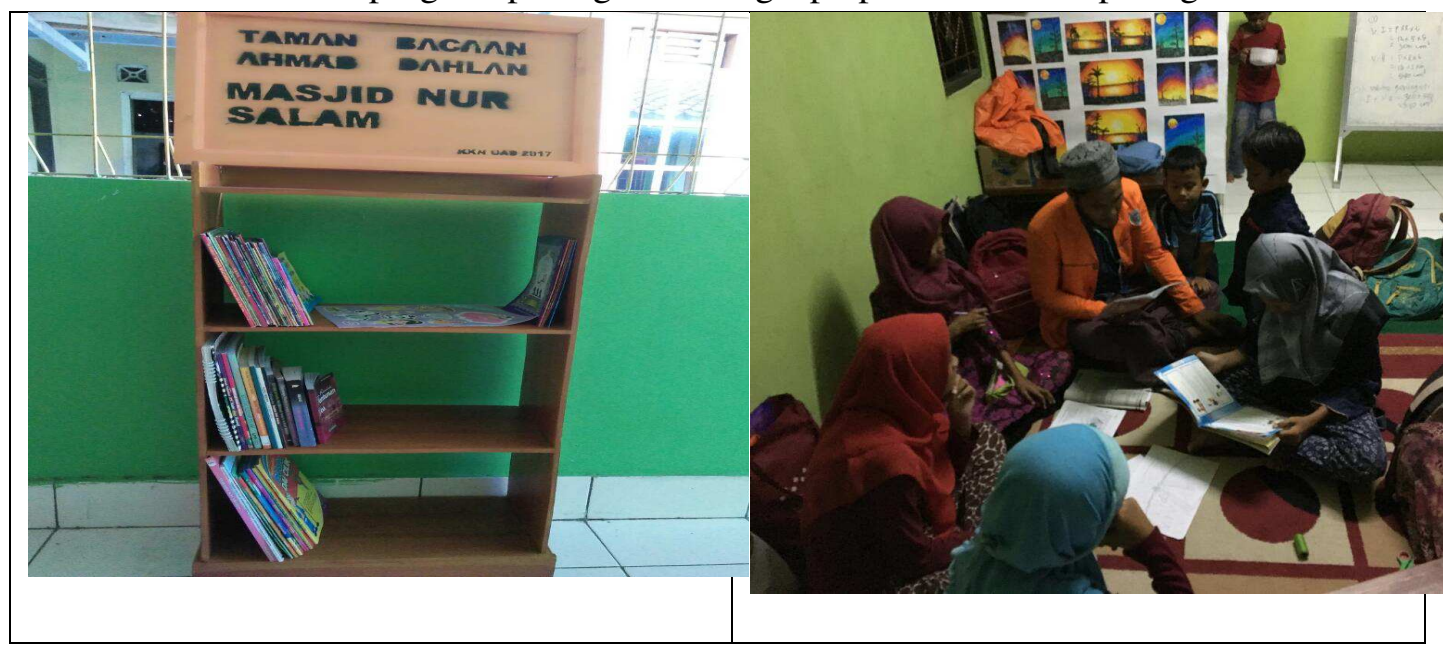




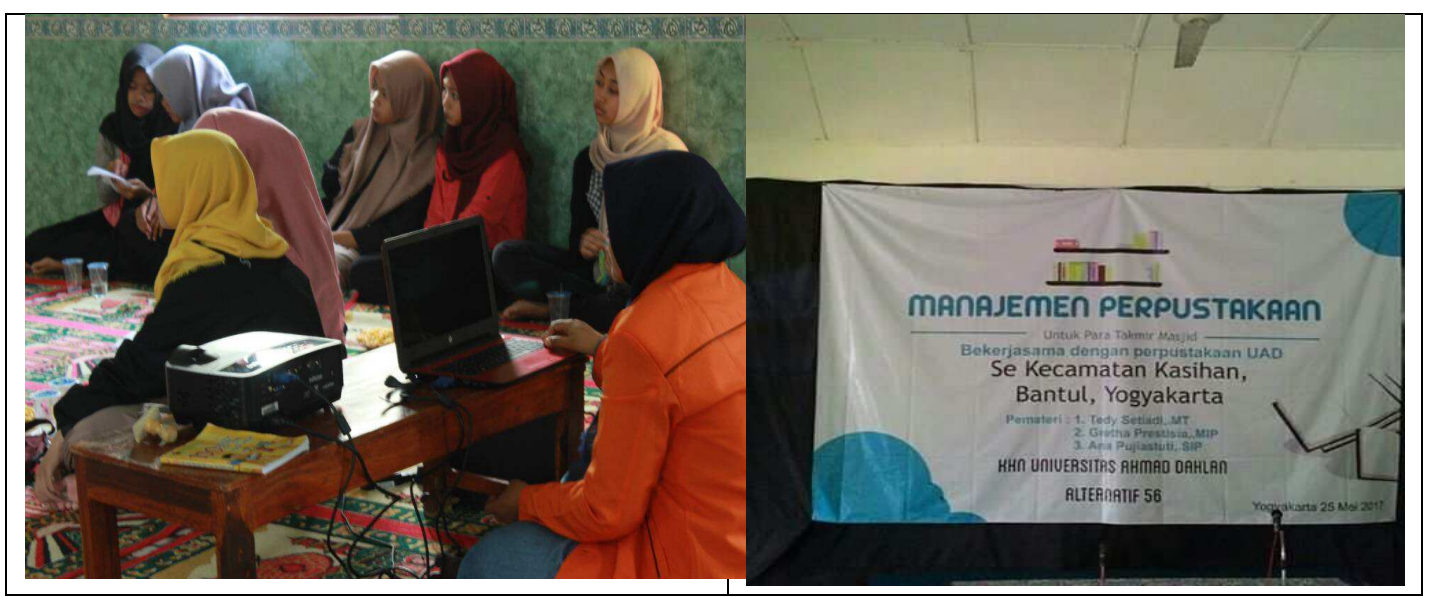

Gambar 4. Aktivitas mahasiswa KKN UAD dan masyarakat desa Menayu Lor, Mrisi dan Beton dalam program peningkatan fungsi perpustakaan desa

Dari gambar 4 terlihat program KKN di Desa Menayu Lor, Mrisi dan Beton dapat terlaksana dengan partisipasi masyarakat yang cukup tinggi dengan kata lain dapat memperdayakan masyarakat dalam program-program yang telah direncanakan. Dampak dari kegiatan KKN ini adalah: 1) tercipta kesadaran masyarakat akan pentingnya membaca, 2) tersedianya sarana ruang baca untuk umum, 3) masyarakat bertambah ilmunya dari buku-buku yang disediakan, 4) masyarakat bertambah ilmu untuk mengelola perpustakaan yang baik.

\section{KESIMPULAN}

Program KKN UAD dalam memberdayakan masyarakat Desa Menayu Lor, Mrisi dan Beton terhadap pengelolaan perpustakaan desa terlaksana dengan baik.

\section{DAFTAR PUSTAKA}

Basuki, Sulistyo. 1992. Kepustakawanan Indonesia: Potensi dan Tantangan. Jakarta: Kesaint Blanc.

Sutarno, Dr. 2008. Membina Perpustakaan Desa. Jakarta: Sagung Seto.

Lina Khoerunnisa (2010). Membangun perpustakaan desa menuju masyarakat berbasis pengetahuan secara merata. Diakses tanggal 8 Juli 2017. Dari Library and Information Science Website. http;//.perpustakaan.com/membangunperpustakaan-desa-menuju-masyarakat-berbasis-pengetahuan-secaramental.html?pdf 